\title{
A REVIEW ARTICLE ON: CORONA VIRUS A RAISING GAINT
}

Suraj G Malpani, Shraddha T Nemane, Vishweshwar M Dharashive, Nilesh N Shinde, Sushil S Kore

Shivlingeshwar College of Pharmacy, Almala Tq. Ausa Dist. Latur, Maharashtra, India.

Article Info: Received 26 March 2020; Accepted 18 April 2020

DOI: https://doi.org/10.32553/jbpr.v9i2.742

Corresponding author: Suraj G Malpani

Conflict of interest statement: No conflict of interest

\section{ABSTRACT}

The 2019-nCoV has been identified as the reason of an outbreak of respiratory illness in Wuhan, Hubei Province, China beginning in December 2019. This outbreak had spread to 19 countries with 11,791 confirmed cases, including 213 deaths, as of January 31, 2020. The WHO declared it as a Public Health Emergency of International Concern. This study analyzed and discussed 70 research articles published until January 31, 2020 for a better understanding of the virology, pathogenesis, mode of transmission, classification, genome structure of this virus. Studies thus far have shown origination in link to a seafood market in Wuhan, but specific animal association has not been confirmed. The reported symptoms include fever, cough, fatigue, pneumonia, headache, diarrhea, hemoptysis, and dyspnea. Preventive measures like masks, hand hygiene practices, avoidance of public contact, case detection, contact tracing, and quarantines are being suggested for reducing the transmission. To date, no specific antiviral treatment is proven effective; hence, infected people primarily rely on symptomatic treatment and supportive care. Although these studies had relevance to control a public emergency, more research need to be conducted to provide valid and reliable ways to manage this kind of public health emergency in both short- and long- term. Coronaviruses (CoV) belong to the genus Coronavirus with its high mutation rate in the Corona viridae. The objective of this review article was to have a primary opinion about the disease mode of transmission, virology in this early stage of COVID-19 outbreak.

Keywords: 2019-nCoV, virology, pathogenesis, genome structure

\section{Introduction}

Coronaviruses (CoV) belong to the genus Coronavirus in the Coronaviridae. All CoVs are pleomorphic RNA viruses characteristically containing crown-shape peplomers with 80-160 nM in size and 27-32 kb positive polarity.[1] Recombination rates of CoVs are very high because of constantly developing transcription errors and RNA Dependent RNA Polymerase (RdRP) jumps.[2] With its high mutation rate, Coronaviruses are zoonotic pathogens that are present in humans and various animals with a wide range of clinical features from asymptomatic course to requirement of hospitalization in the intensive care unit; causing infections in respiratory, gastrointestinal, hepatic and neurologic systems.[3] They were not considered as highly pathogenic for humans until they have been seen with the severe acute respiratory syndrome (SARS) in the Guangdong state of China for the first time in 2002 and 2003. Before these outbreaks, there were the two most known types of CoV as CoV OC43 and CoV 229E that have mostly caused mild infections in people with an adequate immune system. $[3,4]$ Approximately ten years after SARS this time, another highly pathogenic CoV, Middle East Respiratory Syndrome Coronavirus (MERSCoV) has emerged in the Middle East countries.[5] In December 2019, 2019 novel Coronavirus (nCoV), which is another public health problem, has emerged in the Huanan Seafood Market, where livestock animals are also traded, in Wuhan State of Hubei Province in China and has been the focus of global attention due to a pneumonia epidemic of unknown cause.[6] At first, an unknown pneumonia case was detected on December 12, 2019, and possible influenza and other coronaviruses were ruled out by laboratory testing. Chinese authorities announced on January 7, 2020 that a new type of Coronavirus (novel Coronavirus, nCoV) was isolated.[7] This virus was named as 2019-nCoV by WHO on January 12 and COVID-19 on 11 February 2020. As of February 12, 2020, a total of 43.103 confirmed cases and 1.018 deaths have been announced.[8] When given where the first case origi-nated, the infection were transmitted probably as zoonotic agent (from animal to human). The increase in the number of cases in Wuhan city and internationally after closing the market and evacuation of the cases in China has indicated a second 
transmission from human-to-human. New cases are identified, primarily in other Asian countries and in many countries such as the trans-oceanic USA and France (Table 1).The objective of this review article was to have a prelimi-nary opinion about the disease, the ways of treatment, and prevention in this early stage of this outbreak.

\section{VIROLOGY-PATHOGENESIS}

Coronaviruses are viruses whose genome structure is well known among all RNA viruses. Two-thirds of RNA they have encodes viral polymerase (RdRp), RNA synthesis materials, and two large nonstructural polyproteins that are not involved in host response modulation (ORF1a-ORF1b). The other one-third of the genome encodes four structural proteins (spike (S), envelope $(\mathrm{E})$, membrane $(\mathrm{M})$ ve nucleocapsid $(\mathrm{N})$, and the other helper proteins. $[9,10]$ Although the length of the $\mathrm{CoV}$ genome shows high variability for ORF1a/ORF1b and four structural proteins, it is mostly associated with the number and size of accessory proteins. $[9,10]$ The first step in virus infection is the interaction of sensitive human cells with Spike Protein. Genome encoding occurs after entering to the cell and facilitates the expression of the genes that encode useful accessory proteins, which advance the adaptation of CoVs to their human host. [10] Genome changes resulting from recombination, gene exchange, gene insertion, or deletion are frequent among CoVs, and this will take place in future outbreaks as in past epidemics. As a result of the studies, the CoV subfamily is rapidly expanding with new generation sequencing applications that improve the detection and definition of novel CoV species. In conclusion, CoV classification is continually changing. According to the most recent classification of The International Committee on Taxonomy of Viruses (ICTV), there are four genera of thirty-eight unique species.[11] SARS-CoV and MERS-CoV that attach to the host cell respectively bind to cellular receptor angiotensin-converting enzyme 2 (SARS-CoV associated) and cellular receptor of dipeptidyl peptidase 4 (MERSCoV associated).[12] After entering the cell, the viral RNA manifest itself in the cytoplasm. Genomic RNA is compress and polyadenylated, and encodes different structural and non-structural polypeptide genes. These polyproteins are split by proteases that exhibit chymotrypsin-like activity.[10, 12] The resulting complex drives (-) RNA production through both replication and transcription. During replication, full-length (-) RNA copies of the genome are produced and used as a template for full-length (+) RNA genomes.[9, 10] During transcription, a subset of 7-9 sub-genomic RNAs, including those encoding all structural proteins, are produced by discontinuous transcription. Viral nucleocapsids are combined from genomic RNA and R protein in the cytoplasm and then are budded into the lumen of the endoplasmic reticulum. Virions are then released from the previously affected cell through exocytosis. The released viruses can infect kidney cells, liver cells, intestines, and T lymphocytes, as well as the lower respiratory tract, where they form the main symptoms and signs. [12] Remarkably, CDT lymphocytes were found to be lower than 200 cells $/ \mathrm{mm} 3$ in three patients with SARS-CoV infection. MERS-CoV is able to affect human dendritic cells and macrophages in-vitro. $T$ lymphocytes are also a target for the pathogen due to the characteristic CD26 rosettes. This virus can make the antiviral T-cell response irregular due to the stimulation of T-cell apoptosis, thus causing a collapse of the immune system. $[13,14]$

\section{SOURCES \& MODES OF TRANSMISSION}

CoVs have been defined as a novel respiratory tract virus in the samples collected from the person who carry symptoms of respiratory tract infection in 1962.[20] This is a big family of viruses that are common in various animal species, including camels, cattle, cats, and bats. Rarely, animal CoVs can infect humans and, as a result, may spread among humans during epidemics such as MERS, SARS, and COVID-19.[18-19] At the onset of major outbreaks caused by CoVs, palm cats have been proposed to be a natural reservoir of Human CoVs for SARS and dromedary camels for MERS.[15] However, more advanced virological and genetic studies have shown that bats are reservoir hosts of both SARS-CoV and MERS-CoV and before these viruses spread to humans, they use the other responsible animals as intermediate hosts. Studies have reported that most of the bat CoVs are the gene source of alpha-CoV and betaCoVs, while most of the bird CoVs are the gene source of gamma-CoVs and delta-CoVs.[15] In recent studies, it has been observed that the novel virus causing epidemics coincides with the CoV isolated in bats. Presence of wild animal trade in Huanan Seafoods Market where the first cases appeared, supports this finding. $[16,17]$ After the first outbreak, secondary cases began to be reported after approximately ten days. Moreover, while these new patients had no contact with the marketplace, they had a history of contact with humans there. Confirmed recent reports from many infected healthcare workers in Wuhan show that human-to-human transmission can occur. As in SARS and MERS epidemics in the past, human-tohuman transmission has accelerated the spread of the outbreak and case reports have also started from other states of China. The first non-Chinese case of the infection, which spread to the Chinese provinces, and then to the Asian continent, was reported from Thailand on January 13, 2020. The case reported being a Chinese tourist who has traveled to Thailand and had no epidemiologic 
connection with the marketplace.[21] Other cases from oversea countries such as the USA and France have continued to be reported.[22] Often, the human-tohuman transmission occurs with close contact. The transmission primarily occurs when an infected person sneezes and through the respiratory droplets produced just as the spread of influenza and other respiratory pathogens. These droplets can settle in the mouth or nasal mucosa and lungs of people with inhaled air. Currently, it remains unclear whether a person can be infected by COVID-19 by touching an infected surface or object and then touching their mouth, nose, or possibly eyes.[23] Typically, like most respiratory viruses, it is considered to be the most contagious when people are most symptomatic. However, cases, who were infected from an asymptomatic person in the prodrome period of COVID-19, were also reported. Sufficient data are not available on infectiousness of the disease and research is ongoing.[24]

\section{CLASSIFI CATION OF CORONAVIRUSES}

The types or classification of Corona viruses depend on genomic organization, similarities in genomic pattern, antigenic characterstics of viral proteins, replication proceduers, and structural proporties of virions, pathogenic, cytopathogenic and physicochemical properties [25]. The Coronaviruses (CoVs) are species of virus belonging to the Nidovirales order, which includes Coronaviridae, Arteriviridae, Roniviridae and Mesoniviridae families [26]. The Coronaviridae family is the largest one of the four families, by its genomic sizes of coronaviridae range from 26 to $32 \mathrm{~kb}$ [27]. Coronaviridae virus family subdivided into two subfamilies, coronavirinae and torovirinae [28]. It is now classified into four genera, Alpha corona virus, Beta corona virus, Gamma corona virus and Delta corona virus. Alpha corona viruses type 1 species have subtype feline FCoV, FECV (Feline Enteric Corona virus) and FIPV (Feline Infectious Peritonitis Virus), the porcine TGEV (Transmissible Gastro- Enteritis Virus), Porcine PEDV (outbreak Diarrhea Virus), PRCoV (Porcine Respiratory Coronavirus) and the canine CCoV. Alpha corona viruses also compromise human CoVs such as HCoV-229E and HCoVNL63, but various bat Corona viruses. Beta corona viruses also infect mammalians, with species such as mice, human with SARS-CoV, HCOV-OC43, HCOV-HKU1, and MERS-CoV, Murine corona virus (MHV) and Bovine Corona virus (BCoV). Gamma corona viruses are specific of birds, with one exception of a beluga whale Corona virus. The delta corona virus genus was created in 2012 and regroups different (HKU11, HKU12, HKU13) Corona virus from mammals to birds [29].

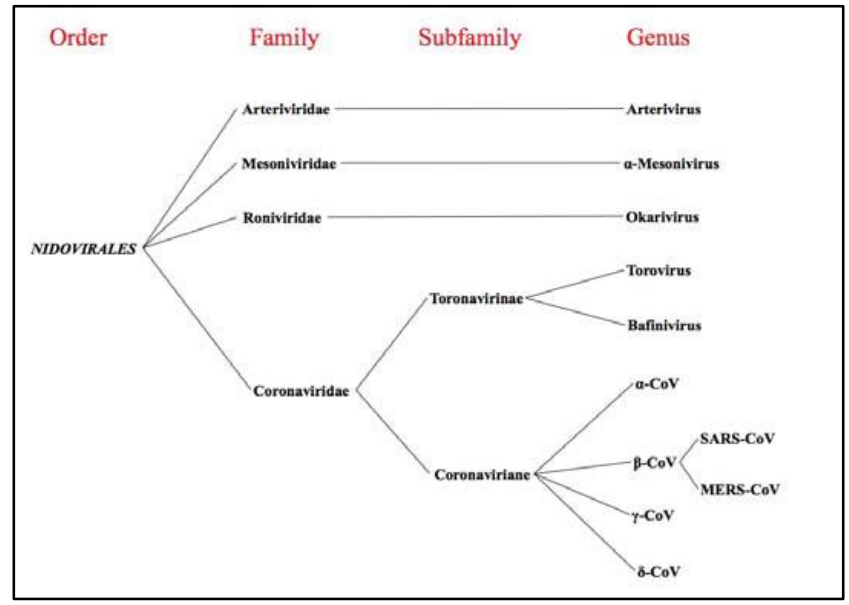

Figure 1: Clasification of corona virus

The first OC43 strain of the human beta corona virus family was identified in 1967 as agents of human respiratory diseases. Until 2002, the new disease found, Severe Acute Respiratory Syndrome (SARS), is caused by a human CoV that emerged in Southern China and Hong Kong. Following the SARS epidemic, two new human coronaviruses named HCov-HKU1 and HCov-NL63 have been identified [31-32].

\section{GENOME STRUCTURE OF CORONAVIRUSES}

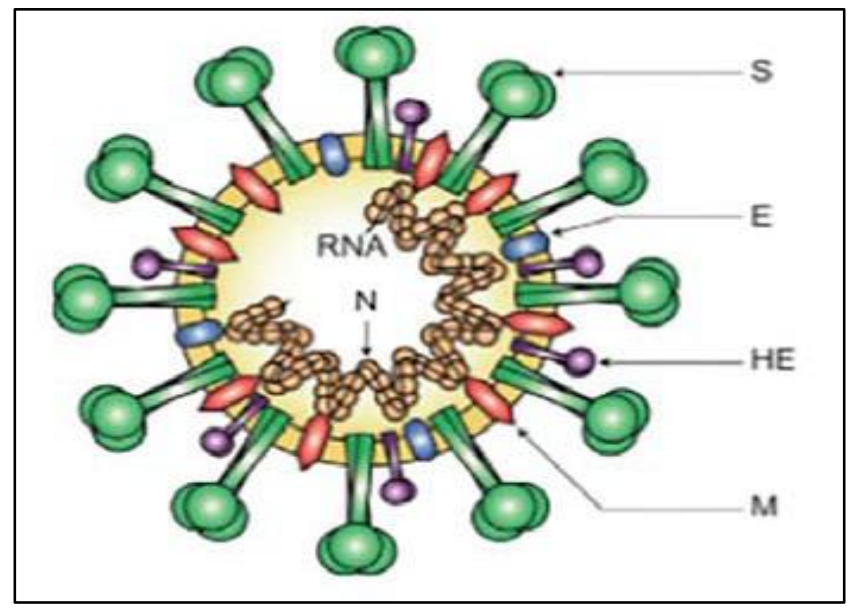

Figure 2: structural proteins of corona virus virion

$\mathrm{N}$ : Nucleocapsid protein;

S: Spike protein,

M: Membrane protein,

$\mathrm{HE}$ :Hemagglutinin-Esterase

E: Envelope protein [30]

Corona viruses encode five structural proteins in their genomes. These are the Spike (S), Membrane (M), Envelope (E) glycoproteinsHemagglutinin Esterase (HE) and Nucleocapsid (N) protein, (Figure 2). All externl proteins and $\mathrm{N}$ protein is present in all virions but $\mathrm{HE}$ is only seen in some beta coronaviruses [33]. In addition to that, it is thought the virus particles are huddled 
together owing to interaction between these proteins $[34,35]$.

S Glycoproteins: S Glycoproteins presents outside the virion and give the virion the typical shape. The $S$ proteins form homotrimers, which permits the formation of sun-like morphologies that give the name of Coronaviruses [36-37]. S proteins bind to the virion membrane ith the help of C-terminal transmembrane regions and

they also interact with $M$ proteins [38]. Virions can be bound to specifi $c$ surface receptors in the plasma membrane of the host cell via the $\mathrm{N}$-terminus of the $\mathrm{S}$ proteins [39].

M Glycoproteins: M Glycoproteins have three transmembrane regions. $M$ proteins are glycosylated in the Golgi apparatus [40-41]. Th is modification of the $M$ protein is crucial for the virion to fuse into the cell and to make protein antigenic [42-43]. Th e M protein plays important role in regenerating virions in the cell. $\mathrm{N}$ protein forms a complex by binding to genomic RNA and $M$ proteincarry out the formation of interacting virions in this endoplasmic reticulum-Golgi apparatus intermediate compartment (ERGIC) with this complex $[40,44,45]$.

E Glycoproteins: E Glycoproteins are small proteins that are formed of approximately 76 to 109 amino acids. About 30 amino acids in the $\mathrm{N}$-terminus of the $\mathrm{E}$ proteins permits attachment to the membrane of viruses [46]. In addition, coronavirus E proteins play important role in the assembly and morphogenesis of virions within the cell. In one study coronavirus $\mathrm{E}$ and $\mathrm{M}$ proteins were expressed together with mammalian expression vectors to form virus-like structures within the cell [47-48]. In another study, there was a significant loss in the ability of the recombinant mouse hepatitis virus (MHV) and SARS viruses to elicit $E$ protein expression in the genome to support this status $[49,50]$. $\mathrm{N}$ Proteins: $\mathrm{N}$ proteins are phosphoproteins that are able to attach the helix and have flexible structure of viral genomic RNA. It plays an key role in virion structure, reduplication and transcription of corona viruses, because the $\mathrm{N}$ protein present in both the replication/ transcriptional areas of the coronaviruses and the ERGIC region where the virus is collected [4451].

\section{FUTURE STUDIES}

Many of the information still lacking, here is list of the required studies to improve our understand for 2019$\mathrm{nCoV}$. The main further studies required are the following

1. Distribution of 2019-nCoV among the age range,

2. How the human body response for the 2019-nCoV
3. How the people whom already infected with SARS before response for 2019-nCoV

4. How the 2019-nCoV effect on the pregnant women and if there is a health risk for transmission of virus to fetus

5. How the virus effect on the people with cancer diseases

6. Does the transmission to 2019-nCoV infection induce the activity of others virus infections such as HIV

7. More information is required to detect the animal source of the virus,

8. Pathogenicity of 2019-nCoV and occurrence the mutation among different patient,

9. Incubation period, epidemic curve, viral kinetics, transmission route, pathogenesis,

10. Treatment response to antivirals among the severe cases,

11. 11. Why the virus need long incubation period,

12. Why the human body take long period in a response for the infections.

The challenges now naturally covers yet have no effective medication that has resulted. Developing technology is going to be obtaining important insight about structure of CoVs protein to define the process of how protein cause disease and understanding the protein-protein and protein- RNA interaction will significantly improve our ability to design vaccines. In the meantime, molecular modelling methods make available important solutions to the struggle.

\section{CONCLUSIONS}

Coronaviruses (CoVs) are a different family of viruses that interact at multiple levels with components of host cells taking this advantage of some of the cellular machineries for replication and multiplication. Various are known about the molecular biology of CoVs but extra information is required to learn. For example, many of the non- structural and necessary proteins encoded by these viruses remain non characterized with unknown function, and it will be important to know mechanisms of action for these proteins as well as defining their activity in viral replication and pathogenesis. The challenge now is to incorporate advance techniques in the investigative efforts done to understand further the biology of CoVs. However, these experimental studies made quite precise, to be dangerous and costly, most importantly 3rd degree with these crudity level laboratories, it remains limited around the world. Lately, especially in the United States, Taiwan, Switzerland, European Union member countries, including Computational Molecular Modeling Studies are effective in removing this deficit, and oft en have an increased use (Bisson, WH, 2012). Due to work and difficulty are developed vaccines that naturally cover yet have non effective medication that has 
resulted. Developing technology is going to be getting valuable insight about structure of CoVs protein to define the mechanism of how protein cause disease and understanding the protein-protein and protein- RNA interaction will significantly improve our ability to design vaccines. In the meantime, molecular modeling procedures provide significant solutions to the struggle.

\section{REFERENCES}

1. Woo PC, Huang Y, Lau SK, Yuen KY. Coronavirus genomics and bioinformatics analysis. Viruses 2010;2:1804-20.

2. Drexler, J.F., Gloza-Rausch, F., Glende, J., Corman, V.M., Muth,D., Goettsche, M., Seebens, A., Niedrig, M., Pfefferle, S., Yordanov, S., Zhelyazkov, L., Hermanns, U., Vallo, P., Lukashev, A.,Muller, M.A., Deng, H., Herrler, G., Drosten, C., 2010. Genomic characterization of severe acute respiratory syndrome-relatedcoronavirus in European bats and classification of coronaviruses based on partial RNA-dependent RNA polymerase gene sequences. J. Virol. 84, 11336-11349.

3. Yin, Y., Wunderink, R. G.. MERS, SARS and other coronaviruses as causes of pneumonia. Respirology, 2018; 23(2): 130-137.

4. Peiris, J. S. M., Lai S. T., Poon L. et. al. (2003). Coronavirus as a possible cause of severe acute respiratory syndrome. The Lancet, 2003; 361(9366): 1319-1325.

5. Zaki AM, van Boheemen S, Bestebroer TM, Osterhaus AD, Fouch ier RA. Isolation of a novel coronavirus from a man with pneumonia in Saudi Arabia. N. Engl. J. Med. 2012; 367: 181420.

6. Seven days in medicine: 8-14 Jan 2020. BMJ 2020;368: m132. 31948945

7. Imperial College London. Report 2: estimating the potential total number of novel coronavirus cases in Wuhan City, China. Jan2020.www.imperial.ac.uk/mrc-globalinfectiousdisease analysis /news--wuhan-coronavirus.

8. European Centre for Disease Prevention and Control data. Geographical distribution of 2019- nCov cases. Available online: (https://www.ecdc.europa.eu/en/geographical-distribution2019-ncov-cases) (accessed on 05 February 2020)

9. Luk H. K., Li X., Fung J., Lau S. K., Woo P. C. (2019). Molecular epidemiology, evolution and phylogeny of SARS coronavirus. Infection, Genetics and Evolution. 2019; 71:21-30

10. Coronavirinae in ViralZone. Available online: https://viralzone. expasy.org/785 (accessed on 05 February 2019).

11. Subissi, L.; Posthuma, C.C.; Collet, A.; Zevenhoven-Dobbe, J.C.; Gorbalenya, A.E.; Decroly, E.; Snijder, E.J.; Canard, B.; Imbert, I. One severe acute respiratory syndrome coronavirus protein complex integrates processive RNA polymerase and exonuclease activities. Proc. Natl. Acad. Sci. USA 2014, 111, E3900-E3909.

12. Lambeir, A.M.; Durinx, C.; Scharpe, S.; De Meester, I. Dipeptidylpeptidase IV from bench to bedside: An update on structural properties, functions, and clinical aspects of the enzyme DPP IV. Crit. Rev. Clin. Lab. Sci. 2003, 40, 209-294.

13. Chu, H.; Zhou, J.; Wong, B.H.; Li, C.; Cheng, Z.S.; Lin, X.; Poon, V.K.; Sun, T.; Lau, C.C.; Chan, J.F.; et al. Productive replication of Middle East respiratory syndrome coronavirus in monocytederived dendritic cells modulates innate immune response. Virology 2014, 454-455, 197-205.

14. Zhou, J.; Chu, H.; Li, C.; Wong, B.H.; Cheng, Z.S.; Poon, V.K.; Sun, T.; Lau, C.C.; Wong, K.K.; Chan, J.Y.; et al. Active replication of Middle East respiratory syndrome coronavirus and aberrant induction of inflammatory cytokines and chemokines in human macrophages: Implications for pathogenesis. J. Infect. Dis. 2014, 209,1331-1342.

15. Yin, Y., Wunderink, R. G.. MERS, SARS and other coronaviruses as causes of pneumonia. Respirology, 2018; 23(2): 130-137.
16. Seven days in medicine: 8-14 Jan 2020. BMJ 2020;368:m132.31948945

17. Gralinski L.; Menachery V; Return of the Coronavirus: 2019nCoV, Viruses 2020, 12(2), 135

18. Coronavirinae in ViralZone. Available online: https://viralzone. expasy.org/785 (accessed on 05 February 2019).

19. Chu, H.; Zhou, J.; Wong, B.H.; Li, C.; Cheng, Z.S.; Lin, X.; Poon, V.K.; Sun, T.; Lau, C.C.; Chan, J.F.; et al. Productive replication of Middle East respiratory syndrome coronavirus in monocytederived dendritic cells modulates innate immune response. Virology 2014, 454-455, 197-205.

20. Hamre, D., Procknow, J. J. A new virus isolated from the human respiratory tract. Proceedings of the Society for Experimental Biology and Medicine, ;1966 121(1): 190-193.

21. Hui D.S.; Azhar E.I:;Madani T.A.; Ntoumi F.; Kock R.; Dar O.; Ippolito G.; Mchugh T. D.;Memish Z.;Drosten C.;Zumla A.; Petersen E.; The continuing 2019-nCoV epidemic threat of novel coronaviruses to global health -The latest 2019 novel coronavirus outbreak in Wuhan, China. Int J Infect Dis, 2020 (91) ,264- 266

22. Holshue M.L.; DeBolt C.; Lindquist S.;Lofy K.H.; Wiesman J.; Bruce H.; Spitters C.; Ericson K.; Wilkerson S.; Tural A.; Diaz G.; Cohn A.;et al. First Case of 2019 Novel Coronavirus in the United States The New England Journal of Medicine 2020.

23. WHO. Emergencies preparedness, response. Pneumonia of unknown origin - China. Disease outbreak news. Available online: https:// HYPERLINK "http://www.who.int/csr/don/12january-2020-novel-coronavirus-china/en/" www.who.int/ csr/ don/12-january-2020-novel-coronavirus-china/en/ ( accessed on 05 February 2020) Wallrauch

24. Rothe C., Schunk M., Sothmann P., Bretzel G., Froeschl G., C., Zimmer T., Thiel V., Janke C., Transmission of 2019-nCoV Infection from an Asymptomatic Contact in Germany, 30.01.2020 DOI:10.1056/NEJMc2001468

25. Lai MM, Cavanagh D. The molecular biology of coronaviruses. Adv Virus Res. 1997; 48: 1-100. https://goo.gl/AUaxWf

26. Zirkel F, Kurth A, Quan PL, Briese T, Ellerbrok H, Pauli G, et al. An Insect Nidovirus Emerging from a Primary Tropical Rainforest. $M$ Bio. 2011; 2: e00077-11. https://goo.gl/bpBvNn

27. Gorbalenya AE, Enjuanes L, Ziebuhr J, Snijder EJ. Nidovirales: evolving the largest RNA virus genome. Virus Research. 2006; 117: 17-37.

28. https://goo.gl/A2FJCP

29. De Groot RJ, Baker SC, Baric R, Enjuanes L, Gorbalenya AE, Holmes KV, et al. Family Coronaviridae. In Virus Taxonomy; Ninth Report of the

30. International Committee on Taxonomy of Viruses. pp. 806-828. Edited by King AMQ, Adams MJ, Carstens EB, Lefkowitz EJ, editors. Oxford: Elsevier

31. Academic Press.

32. Susanna KPL, Kenneth SML, Alan KLT, Chung Tong S, Ming Wang, Garnet, Choi KV, et al. Recent Transmission of a Novel Alpha coronavirus, Bat Coronavirus HKU10, from Leschenault'sRousettes to Pomona Leaf- Nosed Bats: First Evidence of Interspecies Transmission of Coronavirus between Bats of Different Suborders. J Virol. 2012; 86: 11906-11918. https://goo.gl/Xafpnc

33. Susan RW, Julian LL. Coronavirus Pathogenesis. Adv Virus Res. 2011; 81: 85-164. https://goo.gl/rONydb

34. Van der Hoek, Pyrc K, Jebbink MF, Vermeulen-Oost W, Berkhout RJ,

35. Wolthers $\mathrm{KC}$, et al. Identifi cation of a new human coronavirus. Nat Med. 2004;

36. 32: 368-373. https://goo.gl/X84rqQ

37. 10. Woo PC, Lau SK, Chu CM, Chan KH, Tsoi HW, Huang Y, et al. Characterization and complete genome sequence of a novel coronavirus, coronavirus HKU1, from patients with pneumonia. J Virol. 2005; 79: 884-895. https://goo.gl/Ln6iSB 
38. Lissenberg A, Vrolijk MM, van Vliet AL, Langereis MA, de GrootMijnes JD, Rottier PJ, et al. Luxury at a cost? Recombinant mouse hepatitis viruses expressing the accessory hem agglutinin esterase protein display reduced fitness in vitro. J Virol. 2005; 79: 15054-63. https://goo.gl/NT5Lp7

39. De Haan CA, Rottier PJ. Molecular interactions in the assembly of coronaviruses. Adv Virus Res. 2005; 64: 165-230. https://goo.gl/CSUCX2

40. Masters PS. The molecular biology of coronaviruses. Adv Virus Res. 2006; 66: 193-292. https://goo.gl/x66XSJ

41. 30. Susan RW, Julian LL. Coronavirus Pathogenesis. Adv Virus Res. 2011; 81: 85-164. https://goo.gl/rONydb

42. Graham RL, Baric RS. Recombination, reservoirs, and the modular spike: mechanisms of coronavirus cross-species transmission. J Virol. 2010; 84: 3134-3146. https://goo.gl/89BVoZ

43. Tan YJ, Lim SG, Hong W. Characterization of viral proteins encoded by the SARS-coronavirus genome. Antiviral Res. 2005; 65: 69-78. https://goo.gl/ J8d3eD

44. Chinese SMEC. Molecular evolution of the SARS coronavirus during the course of the SARS epidemic in China. Science. 2004; 303: 1666-1669. https://goo.gl/2jO42w

45. Lewicki DN, Gallagher TM. Quaternary structure of coronavirus spikes in complex with carcinoembryonic antigen- related cell adhesion molecule cellular receptors. J Biol Chem. 2002; 277: 19727-19734. https://goo.gl/QTGQol

46. de Haan CA, Masters PS, Lili Kuo, Harry Vennema, Peter JM, Rottier. Coronavirus particle assembly: primary structure requirements of the membrane protein. J Virol. 1998; 72: 68386850. https://goo.gl/czPxHp

47. Niemann H, Geyer R, Klenk HD, Linder D, Stirm S, Wirth $M$. The carbohydrates of mouse hepatitis virus (MHV) A59: structures of the O-glycosidically linked oligosaccharides of glycoprotein E1. EMBO J. 1984; 3: 665-670.https://goo.gl/aXoN3d

48. de Haan CA, de Wit M, Kuo L, Montalto-Morrison C, Haagmans $B L$, Weiss SR, et al. The glycosylation status of the murine hepatitis coronavirus $M$ protein affects the interferogenic capacity of the virus in vitro and its ability to replicate in the liver but not the brain. Virology.2003; 312: 395-406. https://goo.gl/AYsmyB

49. Wissink EH, Kroese MV, Maneschijn Bonsing JG, Meulenberg JJ, van Rijn PA, Rijsewijk FA, et al. Signifi cance of the oligosaccharides of the porcine reproductive and respiratory syndrome virus glycoproteins GP2a and GP5 for infectious virus production. J Gen Virol. 2004; 85: 3715-3723. https://goo.gl/LmtXNO

50. Escors D, Ortego J, Enjuanes L. The membrane M protein of the transmissible gastroenteritis coronavirus binds to the internal core through the carboxyterminus. Adv Exp Med Biol. 2001; 494: 589-593. https://goo.gl/Erg1Yi

51. Narayanan K, Makino S. Characterization of nucleocapsid-M protein interaction in murine coronavirus. Adv Exp Med Biol. 2001; 494:577-582. https://goo.gl/MkAA2B

52. Raamsman MJB, Locker JK, de Hooge A, de Vries AA, Griffi ths G, Vennema $\mathrm{H}$, et al. Characterization of the coronavirus mouse hepatitis virus strain A59 small membrane protein E. J Virol. 2000; 74: 2333-2342.https://goo.gl/GwygyF

53. Baudoux P, Carrat C, Besnardeau L, Charley B, Laude H. Coronavirus pseudo particles formed with recombinant $M$ and $E$ proteins induce alpha interferon synthesis by leukocytes. J Virol. 1998; 72: 8636-8643. https://goo.gl/Fzrwdb

54. Bos EC, Luytjes W, van der Meulen HV, Koerten HK, Spaan WJ. The production of recombinant infectious DI-particles of a murine coronavirus in the absence of helper virus. Virology. 1996; 218: 52-60.

55. https://goo.gl/4NHDYQ

56. DeDiego ML, Alvarez E, Almazan F, Rejas MT, Lamirande E, Roberts $A$, et al. A severe acute respiratory syndrome coronavirus that lacks the $\mathrm{E}$ gene is attenuated in vitro and in vivo. J Virol. 2007; 81: 1701-13.https://goo.gl/zv5cyu

57. Kuo L, Masters PS. The small envelope protein $E$ is not essential for murine coronavirus replication. J Virol 2003; 77: 4597-4608. https://goo.gl/RT1og2

58. Stertz S, Reichelt M, Spiegel M, Kuri T, Martinez Sobrido L, Garcia Sastre A et al. The intracellular sites of early replication and budding of SARScoronavirus. Virology 2007; 361: 304-15 https://goo.gl/LfTwph 